Research Paper

\title{
Genetic Variations of Melatonin Receptor Type 1A are Associated with the Clinicopathologic Development of Urothelial Cell Carcinoma
}

Yung-Wei Lin ${ }^{1,2}$, Shian-Shiang Wang3, 4, 5, Yu-Ching Wen2, 6, Min-Che Tung, 7, Liang-Ming Lee2, 6, Shun-Fa Yang ${ }^{5,8}$, Ming-Hsien Chien ${ }^{1,9 凶}$

1. Graduate Institute of Clinical Medicine, Taipei Medical University, Taipei, Taiwan;

2. Department of Urology, Wan Fang Hospital, Taipei Medical University, Taipei, Taiwan;

3. Division of Urology, Department of Surgery, Taichung Veterans General Hospital, Taichung, Taiwan;

4. School of Medicine, Chung Shan Medical University, Taichung, Taiwan;

5. Institute of Medicine, Chung Shan Medical University, Taichung, Taiwan;

6. Department of Urology, School of Medicine, College of Medicine, Taipei Medical University, Taipei, Taiwan;

7. Department of Surgery, Tungs' Taichung Metro Harbor Hospital, Taichung, Taiwan;

8. Department of Medical Research, Chung Shan Medical University Hospital, Taichung, Taiwan;

9. Department of Medical Education and Research, Wan Fang Hospital, Taipei Medical University, Taipei, Taiwan.

$\triangle$ Corresponding authors: Ming-Hsien Chien, PhD, Graduate Institute of Clinical Medicine, Taipei Medical University, 250 Wu-Hsing Street, Taipei 11031 , Taiwan; Phone: 886-2-27361661, ext. 3237; Fax: 886-2-27390500; E-mail: mhchien1976@gmail.com or Shun-Fa Yang, PhD, Institute of Medicine, Chung Shan Medical University, 110 Chien-Kuo N. Road, Section 1, Taichung 402, Taiwan; Phone: 886-4-2473959, ext. 34253; Fax: 886-4-24723229; E-mail: ysf@csmu.edu.tw

(c) Ivyspring International Publisher. This is an open access article distributed under the terms of the Creative Commons Attribution (CC BY-NC) license (https://creativecommons.org/licenses/by-nc/4.0/). See http://ivyspring.com/terms for full terms and conditions.

Received: 2017.04.18; Accepted: 2017.07.14; Published: 2017.09.04

\begin{abstract}
Melatonin counteracts tumor occurrence and tumor cell progression in several cancer types in vitro and in vivo. It acts predominantly through its melatonin receptor type IA (MTNRIA), and genetic variations of MTNRIA affect the susceptibility several diseases and cancer. The purpose of this study was to explore the effect of MTNRIA gene polymorphisms on the susceptibility to and clinicopathological characteristics of urothelial cell carcinoma (UCC). We recruited 272 patients with UCC and 272 normal controls to analyze three common single-nucleotide polymorphisms (SNPs) (rs2119882, rs13140012, and rs6553010) of MTNRIA related to cancer risk and clinicopathological relevance according to a TaqMan-based real-time polymerase chain reaction (PCR). We found that these three SNPs of MTNRIA were not associated with UCC susceptibility. However, patients with UCC who had at least one G allele of MTNRIA rs6553010 (in intron 1) were at higher risk (1.768-fold, 95\% confidence interval: 1.068 1.849) of developing an invasive stage $(p<0.026)$, compared to those patients with AA homozygotes. In conclusion, polymorphic genotypes of rs6553010 of MTNRIA might contribute to the ability to predict aggressive phenotypes of UCC. This is the first study to provide insights into risk factors associated with intronic MTNRIA variants in the clinicopathologic development of UCC in Taiwan.
\end{abstract}

Key words: Melatonin receptor type 1A; Single-nucleotide polymorphisms; Urothelial cell carcinoma; Clinicopathologic development.

\section{Introduction}

Urothelial cell carcinoma (UCC) arises from the epithelial lining of the entire urinary tract, including the urinary bladder, ureter, and kidneys and has histologic features similar to those of cell carcinoma and is considered to have an analogous etiology [1]. UCC comprises more than $90 \%$ of bladder cancers in both genders. The worldwide age-standardized incidence rates (per 100,000 person/year) of bladder cancer are 9.0 for men and 2.2 for women [2]. In Taiwanese, bladder cancer is the ninth leading malignancy among men and the sixteenth leading malignancy among women with respective incidences 
of about 8.82 and 3.11. Mortality rates of bladder cancer ranked $12^{\text {th }}$ among all cancer deaths for men and $13^{\text {th }}$ among women [3]. The best-known risk factors are tobacco use and aromatic amine exposure, but in Taiwan, arsenic exposure in potable water and traditional herbs containing aristolochic acid are unique risk factors [4-7]. In addition to environmental and dietary factors, recent articles emphasized the importance of genetic factors in the development of UCC [8-10].

Melatonin (N-acetyl-5-methoxytryptamine) is a hormone mainly produced by the pineal gland and other organs [11]. It has many protective roles in several physiological areas such as circadian rhythm control, seasonal reproduction, effective endogenous free radical scavengers, and anti-apoptosis in normal cells [12-16]. On the contrary, melatonin also plays a vital oncostatic role in different cancers through antiproliferative, anti-invasive, anti-metastatic and proapoptotic actions, stimulation of anticancer immunity, modulation of oncogene expression, and its anti-inflammatory, antioxidant, and antiangiogenic effects [17-23]. Melatonin has to bind to its membranous $G$ protein-coupled receptors to execute its cellular functions. Melatonin receptors are divided into type Ia (MTNR1A or $\mathrm{MT}_{1}$ ) and Ib (MTNR1B or $\mathrm{MT}_{2}$ ) with high binding affinity, and are largely responsible for mediating the downstream effects of melatonin [24]. It is widely accepted that melatonin mostly binds to MTNR1A to exhibit it anticancer effects [18, 25]. Higher MTNR1A expression was reported to be correlated with a less-malignant histologic subtype of breast cancer and a higher survival rate of breast cancer patients [26]. A similar correlation was also found in oral squamous cell carcinoma [27]. To the present, little research has been conducted into melatonin and its anticancer activity in urothelial cancer.

Among DNA sequence variations, single-nucleotide polymorphisms (SNPs) are the most common event. The variant frequency occurs in more than $1 \%$ of the population, and correlates with disease susceptibility [28]. Previous studies demonstrated that SNPs of MTNR1A were linked to several kinds of disease, including coronary artery disease, calcium nephrolithiasis, and polycystic ovary syndrome [29-31]. A recent study further disclosed that MTNR1A polymorphisms interact with environment factors to possibly raise oral-cancer susceptibility and even development of an advanced clinical stage and metastatic status [32]. Although associations of genetic polymorphisms of MTNR1A with several diseases and cancer were disclosed, knowledge of potential roles of MTNR1A genetic polymorphisms in susceptibility to UCC is still lacking. In this study, we intended to explore associations of polymorphisms within the MTNR1A gene with UCC risk and the clinicopathologic development of UCC in Taiwanese patients.

\section{Materials and methods}

\section{Study subjects and specimen collection}

In 2010 2013, we recruited 272 patients with urothelial carcinoma, diagnosed at Taichung Veteran General Hospital in Taichung, Taiwan. There were 179 male and 93 female patients. For the control group, 272 participants with a similar male-to-female ratio and age distribution were enrolled in the study. This control group had no self-reported history of cancer at any site and was included from among those undergoing a physical examination at the hospital. Both case and control groups were reviewed for exposure history to tobacco consumption. The staging of urothelial carcinoma was according to the American Joint Committee on Cancer (AJCC) system, including the primary tumor extent, lymph node involvement, and distant organ metastasis status at the moment of disease diagnosis. Cancer cell differentiation was determined by histopathologic grading and examination by a pathologist. Tumors were classified as superficial tumors (pT0 1, $n=165$ ) or invasive tumors (pT2 4, $n=107)$. Metastasis into lymph nodes was detected in 28 cases $(10.3 \%)$, and four patients $(1.5 \%)$ had distal metastasis. The study was approved by the Institutional Review Board (IRB) of Taichung Veteran General Hospital (IRB no. CF11094), and informed written consent was obtained from each participant. Whole-blood specimens collected from controls and UCC patients were placed in tubes containing ethylenediaminetetraacetic acid (EDTA), immediately centrifuged, and then stored at $-80^{\circ} \mathrm{C}$.

\section{Genomic DNA extraction and MTNRIA polymorphism selection}

Genomic DNA was extracted using a QIAamp DNA Blood Mini Kit (Qiagen, Valencia, CA, USA) based on the manufacturer's instructions as previously described [33]. In this study, we selected three SNPs of the MTNR1A gene from data of the International HapMap Project as previously described [32]. We included -184T/C (rs2119882) in the promoter region. Rs13140012 and rs6553010, which are located in intron 1 of MTNR1A, were selected in this study since these two SNPs were found to modify the binding affinities of several transcription factors [30].

\section{Real-time polymerase chain reaction (PCR)}

Allelic discrimination for the MTNR1A SNPs, 
rs2119882 (Assay ID: C_16100974_10), rs13140012 (Assay ID: C_31861431_10), and rs6553010 (Assay ID: C_11782809_10), were assessed using a TaqMan assay with an ABI StepOnePlus ${ }^{\mathrm{TM}}$ Real-Time PCR System (Applied Biosystems, Foster City, CA, USA) and further analyzed with SDS vers. 3.0 software (Applied Biosystems, Foster City, CA, USA). The final volume for each reaction was $5 \mu \mathrm{L}$, containing $2.5 \mu \mathrm{L}$ TaqMan Genotyping Master Mix, $0.125 \mu \mathrm{L}$ TaqMan probe mix, and 10 ng genomic DNA. The real-time PCR consisted of initial denaturation at $95^{\circ} \mathrm{C}$ for $10 \mathrm{~min}$, followed by 40 cycles at $95^{\circ} \mathrm{C}$ for $15 \mathrm{~s}$ and finally at $60^{\circ} \mathrm{C}$ for $1 \mathrm{~min}$.

\section{Statistical analysis}

We compared differences in demographic characteristics between urothelial carcinoma patients and the controls using the Mann-Whitney $U$-test and Fisher's exact test. A goodness-of-fit $X^{2}$-test was used to assess Hardy-Weinberg equilibrium (HWE) for biallelic markers. The odds ratios (ORs) and 95\% confidence intervals (CIs) of the risk association of genotype frequencies with clinical and histopathological characteristics were evaluated using multiple logistic regression models. A $p$ value of $<0.05$ was interpreted as being statistically significant. Data were analyzed with SAS statistical software (SAS Institute, Cary, NC, USA).

\section{Results}

Statistical analyses of demographic characteristics of both the case and control groups are shown in Table 1. We found no significant differences in distributions of age, gender, or tobacco use between control participants and UCC patients. Our study population was predominantly male $(62.9 \%)$ with a low proportion of smokers $(25.3 \%$ in the control and $28.5 \%$ in the UCC group). Most patients (60.7\%) were suffering from superficial tumors (stage pTa pT1).

In our recruited control group, the genotype distributions of MTNR1A SNPs rs2119882 and rs13140012 met the Hardy-Weinberg equilibrium in the normal controls $\left(\mathrm{p}=0.449, \mathrm{X}^{2}\right.$ value: 0.574 and $p=0.560, \chi^{2}$ value: 0.340 , respectively). Reconstructed linkage disequilibrium (LD) plots for the three SNPs were previously shown [32]. The genotype distributions and associations between UCC and gene polymorphisms of MTNR1A are shown in Table 2. The distribution of MTNR1A genotypes revealed that the most frequent alleles were heterozygous $\mathrm{T} / \mathrm{C}$ and $\mathrm{A} / \mathrm{T}$ for the rs2119882 and rs13140012 loci, respectively, and homozygous A/A for the rs6553010 locus. There were no significant differences in genotype distributions or associations between urothelial carcinoma patients and the controls for the rs2119882, rs13140012, or rs6553010 SNPs (Table 2).

Table 1. The distributions of demographical characteristics in 272 controls and 272 urothelial cell carcinoma patients.

\begin{tabular}{|c|c|c|c|}
\hline Variable & Controls $(N=272)$ & Patients $(N=272)$ & $p$ value \\
\hline Age (yrs) & $\begin{array}{l}\text { Mean } \pm \text { S.D. } \\
67.79 \pm 10.06\end{array}$ & $\begin{array}{l}\text { Mean } \pm \text { S.D. } \\
68.68 \pm 12.06\end{array}$ & $p=0.349$ \\
\hline \multicolumn{4}{|l|}{ Gender } \\
\hline Male & $181(66.5 \%)$ & $179(65.8 \%)$ & \\
\hline Female & $91(33.5 \%)$ & $93(34.2 \%)$ & $p=0.856$ \\
\hline \multicolumn{4}{|l|}{$\begin{array}{l}\text { Tobacco } \\
\text { consumption }\end{array}$} \\
\hline No & $201(73.9 \%)$ & $196(72.1 \%)$ & \\
\hline Yes & $71(26.1 \%)$ & $76(27.9 \%)$ & $p=0.629$ \\
\hline \multicolumn{4}{|l|}{ Stage } \\
\hline $\begin{array}{l}\text { Superficial tumor } \\
\text { (pTa-pT1) }\end{array}$ & & $165(60.7 \%)$ & \\
\hline $\begin{array}{l}\text { Invasive tumor } \\
(\mathrm{pT} 2-\mathrm{pT} 4)\end{array}$ & & $107(39.3 \%)$ & \\
\hline \multicolumn{4}{|l|}{ Tumor T status } \\
\hline $\mathrm{T} 0$ & & $74(27.2 \%)$ & \\
\hline $\mathrm{T} 1-\mathrm{T} 4$ & & $198(72.8 \%)$ & \\
\hline \multicolumn{4}{|l|}{$\begin{array}{l}\text { Lymph node } \\
\text { status }\end{array}$} \\
\hline No & & $244(89.7 \%)$ & \\
\hline $\mathrm{N} 1+\mathrm{N} 2$ & & $28(10.3 \%)$ & \\
\hline \multicolumn{4}{|l|}{ Metastasis } \\
\hline M0 & & $268(98.5 \%)$ & \\
\hline M1 & & $4(1.5 \%)$ & \\
\hline \multicolumn{4}{|l|}{$\begin{array}{l}\text { Histopathologic } \\
\text { grading }\end{array}$} \\
\hline Low grade & & $39(14.3 \%)$ & \\
\hline High grade & & $233(85.7 \%)$ & \\
\hline
\end{tabular}

Table 2. Distribution frequencies of MTNRIA genotypes in 272 controls and 272 urothelial cell carcinoma patients

\begin{tabular}{|c|c|c|c|}
\hline Variable & $\begin{array}{l}\text { Controls }(N=272) \\
n(\%)\end{array}$ & $\begin{array}{l}\text { Patients }(N=272) \\
n(\%)\end{array}$ & OR $(95 \% \mathrm{CI})$ \\
\hline \multicolumn{4}{|l|}{ rs2119882 } \\
\hline $\mathrm{TT}$ & $113(41.5 \%)$ & $108(39.7 \%)$ & 1.00 \\
\hline $\mathrm{TC}$ & $129(47.4 \%)$ & $119(43.8 \%)$ & $0.965(0.672 \sim 1.387)$ \\
\hline $\mathrm{CC}$ & $30(11.1 \%)$ & $45(16.5 \%)$ & $1.569(0.922 \sim 2.672)$ \\
\hline $\mathrm{TC}+\mathrm{CC}$ & $159(58.5 \%)$ & $164(60.3 \%)$ & $1.079(0.766 \sim 1.520)$ \\
\hline $\begin{array}{l}\text { rs2119882 } \\
\text { Alleles }\end{array}$ & $\begin{array}{l}\text { Controls }(N=544) \\
n(\%)\end{array}$ & $\begin{array}{l}\text { Patients }(N=544) \\
n(\%)\end{array}$ & \\
\hline $\mathrm{T}$ & $355(65.3 \%)$ & $335(61.6 \%)$ & 1.00 \\
\hline $\mathrm{C}$ & $189(34.7 \%)$ & $209(38.4 \%)$ & $1.172(0.915 \sim 1.500)$ \\
\hline \multicolumn{4}{|l|}{ rs13140012 } \\
\hline AA & $111(40.8 \%)$ & $103(37.9 \%)$ & 1.00 \\
\hline AT & $122(44.9 \%)$ & $130(47.8 \%)$ & $1.148(0.797 \sim 1.654)$ \\
\hline $\mathrm{TT}$ & $39(14.3 \%)$ & $39(14.3 \%)$ & $1.078(0.642 \sim 1.810)$ \\
\hline $\mathrm{AT}+\mathrm{TT}$ & $161(59.2 \%)$ & $169(62.1 \%)$ & $1.131(0.802 \sim 1.596)$ \\
\hline $\begin{array}{l}\text { rs13140012 } \\
\text { Alleles }\end{array}$ & $\begin{array}{l}\text { Controls }(N=544) \\
n(\%)\end{array}$ & $\begin{array}{l}\text { Patients }(N=544) \\
n(\%)\end{array}$ & \\
\hline A & $344(63.2 \%)$ & $336(61.8 \%)$ & 1.00 \\
\hline $\mathrm{T}$ & $200(36.8 \%)$ & $208(38.2 \%)$ & $1.065(0.833 \sim 1.361)$ \\
\hline \multicolumn{4}{|l|}{ rs6553010 } \\
\hline AA & $124(45.6 \%)$ & $114(41.9 \%)$ & 1.00 \\
\hline AG & $105(38.6 \%)$ & $103(37.9 \%)$ & $1.067(0.735 \sim 1.548)$ \\
\hline GG & $43(15.8 \%)$ & $55(20.2 \%)$ & $1.391(0.867 \sim 2.233)$ \\
\hline $\mathrm{AG}+\mathrm{GG}$ & $148(54.4 \%)$ & $158(58.1 \%)$ & $1.161(0.827 \sim 1.630)$ \\
\hline $\begin{array}{l}\text { rs6553010 } \\
\text { Alleles }\end{array}$ & $\begin{array}{l}\text { Controls }(N=544) \\
n(\%)\end{array}$ & $\begin{array}{l}\text { Patients }(N=544) \\
n(\%)\end{array}$ & \\
\hline A & $353(64.9 \%)$ & $331(60.8 \%)$ & 1.00 \\
\hline G & $191(35.1 \%)$ & $213(39.2 \%)$ & $1.189(0.930 \sim 1.521)$ \\
\hline
\end{tabular}


As shown in Tables 3 5, we further analyzed genotype frequencies of individual polymorphisms with relevance to the clinicopathological status, including the cancer stage, tumor status, lymph node involvement, metastatic status, and histopathologic grading, in UCC patients. We classified UCC patients into two subgroups. In the first subgroup, patients had homozygous wild-type (WT) alleles; in the other subgroup, they had at least one polymorphic allele. No significant associations of the rs2119882 or rs13140012 gene polymorphisms with the clinicopathologic status were observed (Tables 3, 4). However, subjects with at least one $G$ allele of rs6553010 (AG+GG) exhibited a significantly ( $p=$ $0.026)$ higher risk of 1.768 -fold (95\% CI: $1.041 \sim 2.063$ ) of having the invasive type of UCC compared to their corresponding WT homozygotes (Table 5).

\section{Discussion}

Recently, many studies have shown that polymorphisms of MTNR genes (MTNR1A and MTNR1B) may affect susceptibility to several diseases, such as adolescent idiopathic scoliosis [34], coronary artery disease [29], type 2 diabetes mellitus [35], calcium nephrolithiasis [30], and polycystic ovary syndrome [31], and also influence the clinicopathological development of oral cancer [32]. In the present study, we investigated associations of variants of the MTNR1A gene with the UCC risk and its clinicopathologic development in a Taiwanese population.

Table 3. Distribution frequencies of the clinical status and MTNRIA rs2119882 genotype frequencies of 272 patients with urothelial cell carcinoma

\begin{tabular}{|c|c|c|c|c|}
\hline \multirow[t]{2}{*}{ Variable } & \multicolumn{4}{|c|}{ MTNR1A (rs2119882) } \\
\hline & $\begin{array}{l}\text { TT (\%) } \\
(n=108)\end{array}$ & $\begin{array}{l}\text { TC+CC }(\%) \\
(n=164)\end{array}$ & OR $(95 \%$ CI $)$ & $p$ value \\
\hline \multicolumn{5}{|l|}{ Stage } \\
\hline $\begin{array}{l}\text { Superficial tumor } \\
(\mathrm{pTa} \sim \mathrm{pT} 1)\end{array}$ & $72(66.7 \%)$ & $93(56.7 \%)$ & 1.00 & \\
\hline $\begin{array}{l}\text { Invasive tumor } \\
(\mathrm{pT} 2 \sim \mathrm{pT} 4)\end{array}$ & $36(33.3 \%)$ & $71(43.3 \%)$ & $1.527(0.921 \sim 2.531)$ & $p=0.100$ \\
\hline \multicolumn{5}{|l|}{ Tumor $\mathrm{T}$ status } \\
\hline $\mathrm{T} 0$ & $33(30.6 \%)$ & $41(25.0 \%)$ & 1.00 & \\
\hline $\mathrm{T} 1 \sim \mathrm{T} 4$ & $75(69.4 \%)$ & $123(75.0 \%)$ & $1.320(0.769 \sim 2.267)$ & $p=0.314$ \\
\hline \multicolumn{5}{|l|}{$\begin{array}{l}\text { Lymph node } \\
\text { status }\end{array}$} \\
\hline No & $99(91.7 \%)$ & $145(88.4 \%)$ & 1.00 & \\
\hline $\mathrm{N} 1+\mathrm{N} 2$ & $9(8.3 \%)$ & $19(11.6 \%)$ & $1.441(0.626 \sim 3.316)$ & $p=0.388$ \\
\hline \multicolumn{5}{|l|}{ Metastasis } \\
\hline M0 & $107(99.1 \%)$ & $161(98.2 \%)$ & 1.00 & \\
\hline M1 & $1(0.9 \%)$ & $3(1.8 \%)$ & $1.994(0.205 \sim 19.421)$ & $p=0.545$ \\
\hline \multicolumn{5}{|l|}{$\begin{array}{l}\text { Histopathologic } \\
\text { grading }\end{array}$} \\
\hline Low grade & $11(10.2 \%)$ & $28(17.1 \%)$ & 1.00 & \\
\hline High grade & $97(89.8 \%)$ & $136(82.9 \%)$ & $0.551(0.262 \sim 1.160)$ & $p=0.113$ \\
\hline
\end{tabular}

OR, odds ratio; $\mathrm{CI}$, confidence interval.
Table 4. Distribution frequencies of the clinical status and MTNRIA rs 13140012 genotype frequencies in 272 patients with urothelial cell carcinoma

\begin{tabular}{|c|c|c|c|c|}
\hline \multirow[t]{2}{*}{ Variable } & \multicolumn{4}{|c|}{ MTNR1A (rs13140012) } \\
\hline & $\begin{array}{l}\text { AA (\%) } \\
(n=103)\end{array}$ & $\begin{array}{l}\mathrm{AT}+\mathrm{TT}(\%) \\
(n=169)\end{array}$ & OR $(95 \%$ CI) & $p$ value \\
\hline \multicolumn{5}{|l|}{ Stage } \\
\hline $\begin{array}{l}\text { Superficial tumor } \\
\text { (pTa pT1) }\end{array}$ & $69(67.0 \%)$ & $96(56.8 \%)$ & 1.00 & \\
\hline $\begin{array}{l}\text { Invasive tumor } \\
\text { (pT2 pT4) }\end{array}$ & $34(33.0 \%)$ & $73(43.2 \%)$ & $1.543(0.926 \sim 2.573)$ & $p=0.095$ \\
\hline \multicolumn{5}{|l|}{ Tumor T status } \\
\hline T0 & $29(28.2 \%)$ & $45(26.6 \%)$ & 1.00 & \\
\hline $\mathrm{T} 1 \sim \mathrm{T} 4$ & $74(71.8 \%)$ & $124(73.4 \%)$ & $1.080(0.624 \sim 1.869)$ & $p=0.784$ \\
\hline \multicolumn{5}{|l|}{$\begin{array}{l}\text { Lymph node } \\
\text { status }\end{array}$} \\
\hline No & $94(91.3 \%)$ & $150(88.8 \%)$ & 1.00 & \\
\hline $\mathrm{N} 1+\mathrm{N} 2$ & $9(8.7 \%)$ & $19(11.2 \%)$ & $1.323(0.575 \sim 3.046)$ & $p=0.510$ \\
\hline \multicolumn{5}{|l|}{ Metastasis } \\
\hline M0 & $102(99.0 \%)$ & $166(98.2 \%)$ & 1.00 & \\
\hline M1 & $1(1.0 \%)$ & $3(1.8 \%)$ & $1.843(0.189 \sim 17.960)$ & $p=0.593$ \\
\hline \multicolumn{5}{|l|}{$\begin{array}{l}\text { Histopathologic } \\
\text { grading }\end{array}$} \\
\hline Low grade & $10(9.7 \%)$ & $29(17.2 \%)$ & 1.00 & \\
\hline High grade & $93(90.3 \%)$ & $140(82.8 \%)$ & $0.519(0.242 \sim 1.116)$ & $p=0.089$ \\
\hline
\end{tabular}

OR, odds ratio; $\mathrm{CI}$, confidence interval.

Table 5. Distribution frequencies of the clinical status and MTNRIA rs6553010 genotype frequencies in 272 patients with urothelial cell carcinoma

\begin{tabular}{|c|c|c|c|c|}
\hline \multirow[t]{2}{*}{ Variable } & \multicolumn{4}{|c|}{ MTNR1A (rs6553010) } \\
\hline & $\begin{array}{l}\text { AA (\%) } \\
(n=114)\end{array}$ & $\begin{array}{l}\text { AG+GG } \\
(\%)(n=158)\end{array}$ & OR $(95 \% \mathrm{CI})$ & $p$ value \\
\hline \multicolumn{5}{|l|}{ Stage } \\
\hline $\begin{array}{l}\text { Superficial tumor } \\
\text { (pTa pT1) }\end{array}$ & $78(68.4 \%)$ & $87(55.1 \%)$ & 1.00 & \\
\hline $\begin{array}{l}\text { Invasive tumor } \\
\text { (pT2 pT4) }\end{array}$ & $36(31.6 \%)$ & $71(44.9 \%)$ & $1.768(1.068 \sim 2.928)$ & $p=0.026^{*}$ \\
\hline \multicolumn{5}{|l|}{ Tumor $\mathrm{T}$ status } \\
\hline T0 & $32(28.1 \%)$ & $42(26.6 \%)$ & 1.00 & \\
\hline $\mathrm{T} 1 \sim \mathrm{T} 4$ & $82(71.9 \%)$ & $116(73.4 \%)$ & $1.078(0.628 \sim 1.849)$ & $p=0.786$ \\
\hline \multicolumn{5}{|l|}{ Lymph node status } \\
\hline N0 & $101(88.6 \%)$ & $143(90.5 \%)$ & 1.00 & \\
\hline $\mathrm{N} 1+\mathrm{N} 2$ & $13(11.4 \%)$ & $15(9.5 \%)$ & $0.815(0.372-1.787)$ & $p=0.609$ \\
\hline \multicolumn{5}{|l|}{ Metastasis } \\
\hline M0 & $112(98.2 \%)$ & $156(98.7 \%)$ & 1.00 & \\
\hline M1 & $2(1.8 \%)$ & $2(1.3 \%)$ & $0.718(0.100-5.174)$ & $p=0.741$ \\
\hline \multicolumn{5}{|l|}{$\begin{array}{l}\text { Histopathologic } \\
\text { grading }\end{array}$} \\
\hline Low grade & $13(11.4 \%)$ & $26(16.5 \%)$ & 1.00 & \\
\hline High grade & $101(88.6 \%)$ & $132(83.5 \%)$ & $0.653(0.320-1.335)$ & $p=0.241$ \\
\hline
\end{tabular}

Although MTNR1A gene SNPs (rs2119882, rs13140012, and rs6553010) alone did not contribute to UCC susceptibility in our study, a major finding of this study was the significant association between rs6553010 MTNR1A genotypes and the clinicopathological development of UCC. We observed that the frequency of the $A / G$ and $G / G$ combined genotypes was greater in patients with invasive UCC (44.9\%) than in the controls (31.6\%). This finding is similar to findings from our previous study regarding genetic polymorphisms of MTNR1A which alone were unable to predict the risk of oral 
cancer. However, after being combined with information on carcinogen exposure, a significant effect for predicting oral-cancer susceptibility was observed [32]. It is well-known that tobacco smoking is also the leading risk factor for developing bladder cancer. From a meta-analysis of smoking's effects on bladder cancer, there was an association of increased risks (odds ratios) of about 4.23 for male smokers and 1.35 for female smokers [36]. However, after being combined with information on carcinogen exposure, genetic polymorphisms of MTNR1A still could not predict UCC susceptibility in our recruited populations. This might have been due to a bias in the ratio of individuals with a smoking habit among our recruited UCC patients. In previous SNP-related studies of UCC, significantly higher ratios of individuals with a smoking habit among UCC patients than in the controls were observed [37]. However, we found no significantly different distributions of tobacco use between control participants and UCC patients in this study. In our future work, more UCC patients with a smoking habit should be recruited to further explore the combined effect of MTNR1A genetic variants and exposure to tobacco carcinogens on the risk of UCC.

Melatonin was demonstrated to exert oncostatic effects including antimetastatic activity both in vivo and in vitro in various types of malignancies via the MTNR1A receptor [17-19, 38-40]. Expression of MTNR1A in cancer cells seems to increase the efficacy of melatonin's oncostatic activity. The expression level of MTNR1A was inversely correlated with the invasive abilities of breast cancer cell lines [38]. In clinical specimens, MTNR1A messenger (m)RNA expression was negatively correlated with the malignancy grade of invasive ductal breast carcinomas (IDC). Moreover, higher MTNR1A expression was associated with patients' longer overall survival (OS) in patients with estrogen receptor positive $\left(\mathrm{ER}^{+}\right)$breast cancers who were treated with tamoxifen. MTNR1A was recognized as an independent prognostic factor in $\mathrm{ER}^{+}$tumors for OS and disease-free survival in $\mathrm{ER}^{+}$tumors [26]. Those results indicated that the MTNR1A expression level might affect the invasive ability of breast cancer. In our study, we found that patients with one G allele of MTNR1A rs6553010 had higher risks of developing advanced invasive UCC than those with the WT. Although we still have no evidence that MTNR1A expression can affect the invasive ability of UCC, the intronic rs6553010 SNP is itself a functional polymorphism that exerts a direct effect on MTNR1A gene expression in patients with UCC. Several reports previously indicated that an intronic SNP can affect gene expressions in different diseases and also affect the susceptibility or metastasis in different cancers including UCC [41-45]. Previous reports indicated that some intronic polymorphic variants can induce either alternative or aberrant splicing of mRNA and further affect gene expressions [46]. Moreover, Esposito et al. indicated that another SNP, rs13140012 (A>T mutation), in intron 1 of the MTNR1A gene can affect the binding affinity of several transcription factors [30]. The promoter activity assay in oral cancer showed that a fragment containing exon 1 and intron 1 within the MTNR1A gene showed remarkable transcriptional activity [27]. We assumed that intronic the A/G SNP rs6553010 may act alone or in combination with other yet unidentified functional variants in the gene to influence MTNR1A expression.

Despite our best efforts, a significant proportion of patients suffering from UCC will develop advanced disease, and we do not currently have sufficiently reliable tools to predict who these patients are. In this study, we found a significant association between the invasive UCC type and the rs6553010 A/G and G/G combined genotypes. The rs6553010 G allele may act as a risk factor. In order to precisely evaluate MTNR1A polymorphisms and clinicopathological development of UCC, a much-larger sample size is needed. Ultimately, we suggest that future studies of the functional activities of these polymorphisms and their effects on tumor invasion would help us understand the underlying mechanisms in UCC development.

\section{Acknowledgments}

This study was supported by grant number 106-wf-phd-02 from Wan Fang Hospital, Taipei Medical University.

\section{Competing Interests}

The authors have declared that no competing interest exists.

\section{References}

1. Komiya $Y$, Tsukino H, Nakao H, Kuroda $Y$, Imai H, Katoh T. Human glutathion S-transferase A1 polymorphism and susceptibility to urothelial cancer in the Japanese population. Cancer Lett. 2005; 221: 55-9.

2. Ferlay J, Soerjomataram I, Dikshit R, Eser S, Mathers C, Rebelo M, et al. Cancer incidence and mortality worldwide: sources, methods and major patterns in GLOBOCAN 2012. Int J Cancer. 2015; 136: E359-86.

3. Hung CF, Yang CK, Ou YC. Urologic cancer in Taiwan. Jpn J Clin Oncol. 2016; 46: 605-9.

4. Chen CJ, Kuo TL, Wu MM. Arsenic and cancers. Lancet. 1988; 1: 414-5.

5. Clyne M. Bladder cancer: aristolochic acid--one of the most potent carcinogens known to man. Nat Rev Urol. 2013; 10: 552.

6. Thun MJ, Henley SJ, Calle EE. Tobacco use and cancer: an epidemiologic perspective for geneticists. Oncogene. 2002; 21: 7307-25.

7. Kellen E, Zeegers M, Paulussen A, Vlietinck R, Vlem EV, Veulemans H, et al. Does occupational exposure to PAHs, diesel and aromatic amines interact with smoking and metabolic genetic polymorphisms to increase the risk on bladder cancer?; The Belgian case control study on bladder cancer risk. Cancer Lett. 2007; 245: 51-60.

8. Guirado M, Gil H, Saenz-Lopez P, Reinboth J, Garrido F, Cozar JM, et al. Association between C13ORF31, NOD2, RIPK2 and TLR10 polymorphisms and urothelial bladder cancer. Hum Immunol. 2012; 73: 668-72. 
9. Kim EJ, Jeong P, Quan C, Kim J, Bae SC, Yoon SJ, et al. Genotypes of TNF-alpha, VEGF, hOGG1, GSTM1, and GSTT1: useful determinants for clinical outcome of bladder cancer. Urology. 2005; 65: 70-5.

10. Tung MC, Hsieh MJ, Wang SS, Yang SF, Chen SS, Wang SW, et al. Associations of VEGF-C genetic polymorphisms with urothelial cell carcinoma susceptibility differ between smokers and non-smokers in Taiwan. PLoS One. 2014; 9: e91147.

11. Barrett $\mathrm{P}$, Bolborea $\mathrm{M}$. Molecular pathways involved in seasonal body weight and reproductive responses governed by melatonin. J Pineal Res. 2012; 52: 376-88.

12. Arendt J. Melatonin, circadian rhythms, and sleep. N Engl J Med. 2000; 343: 1114-6.

13. Reiter RJ. The pineal and its hormones in the control of reproduction in mammals. Endocr Rev. 1980; 1: 109-31.

14. Reiter RJ, Tan DX, Terron MP, Flores LJ, Czarnocki Z. Melatonin and its metabolites: new findings regarding their production and their radical scavenging actions. Acta Biochim Pol. 2007; 54: 1-9.

15. Sainz RM, Mayo JC, Rodriguez C, Tan DX, Lopez-Burillo S, Reiter RJ. Melatonin and cell death: differential actions on apoptosis in normal and cancer cells. Cell Mol Life Sci. 2003; 60: 1407-26.

16. Um HJ, Kwon TK. Protective effect of melatonin on oxaliplatin-induced apoptosis through sustained Mcl-1 expression and anti-oxidant action in renal carcinoma Caki cells. J Pineal Res. 2010; 49: 283-90.

17. Reiter RJ. Mechanisms of cancer inhibition by melatonin. Journal of pineal research. 2004; 37: 213-4.

18. Bizzarri M, Proietti S, Cucina A, Reiter RJ. Molecular mechanisms of the pro-apoptotic actions of melatonin in cancer: a review. Expert opinion on therapeutic targets. 2013; 17: 1483-96.

19. Lin YW, Lee LM, Lee WJ, Chu CY, Tan P, Yang YC, et al. Melatonin inhibits MMP-9 transactivation and renal cell carcinoma metastasis by suppressing Akt-MAPKs pathway and NF-kappaB DNA-binding activity. J Pineal Res. 2016; 60: 277-90.

20. Yeh CM, Lin CW, Yang JS, Yang WE, Su SC, Yang SF. Melatonin inhibits TPA-induced oral cancer cell migration by suppressing matrix metalloproteinase-9 activation through the histone acetylation. Oncotarget. 2016; 7: 21952-67.

21. Su SC, Hsieh MJ, Yang WE, Chung WH, Reiter RJ, Yang SF. Cancer metastasis: Mechanisms of inhibition by melatonin. Journal of pineal research. 2017; 62.

22. Reiter RJ, Rosales-Corral SA, Tan DX, Acuna-Castroviejo D, Qin L, Yang SF, et al. Melatonin, a Full Service Anti-Cancer Agent: Inhibition of Initiation, Progression and Metastasis. International journal of molecular sciences. 2017; 18.

23. Ho HY, Lin CW, Chien MH, Reiter RJ, Su SC, Hsieh YH, et al. Melatonin suppresses TPA-induced metastasis by downregulating matrix metalloproteinase-9 expression through JNK/SP-1 signaling in nasopharyngeal carcinoma. Journal of pineal research. 2016; 61: 479-92.

24. Liu J, Clough SJ, Hutchinson AJ, Adamah-Biassi EB, Popovska-Gorevski M, Dubocovich ML. MT1 and MT2 Melatonin Receptors: A Therapeutic Perspective. Annu Rev Pharmacol Toxicol. 2016; 56: 361-83.

25. Tam CW, Mo CW, Yao KM, Shiu SY. Signaling mechanisms of melatonin in antiproliferation of hormone-refractory 22Rv1 human prostate cancer cells: implications for prostate cancer chemoprevention. J Pineal Res. 2007; 42: 191-202

26. Jablonska K, Pula B, Zemla A, Owczarek T, Wojnar A, Rys J, et al. Expression of melatonin receptor MT1 in cells of human invasive ductal breast carcinoma. Journal of pineal research. 2013; 54: 334-45.

27. Nakamura E, Kozaki K, Tsuda H, Suzuki E, Pimkhaokham A, Yamamoto G, et al. Frequent silencing of a putative tumor suppressor gene melatonin receptor 1 A (MTNR1A) in oral squamous-cell carcinoma. Cancer science. 2008; 99: 1390-400.

28. Shastry BS. SNP alleles in human disease and evolution. Journal of human genetics. 2002; 47: 561-6.

29. Samimi-Fard S, Abreu-Gonzalez P, Dominguez-Rodriguez A, Jimenez-Sosa A. A case-control study of melatonin receptor type 1A polymorphism and acute myocardial infarction in a Spanish population. Journal of pineal research. 2011; 51: 400-4.

30. Esposito T, Rendina D, Aloia A, Formicola D, Magliocca S, De Filippo G, et al. The melatonin receptor 1A (MTNR1A) gene is associated with recurrent and idiopathic calcium nephrolithiasis. Nephrology, dialysis, transplantation : official publication of the European Dialysis and Transplant Association European Renal Association. 2012; 27: 210-8.

31. Li C, Shi Y, You L, Wang L, Chen ZJ. Melatonin receptor $1 \mathrm{~A}$ gene polymorphism associated with polycystic ovary syndrome. Gynecologic and obstetric investigation. 2011; 72: 130-4

32. Lin FY, Lin CW, Yang SF, Lee WJ, Lin YW, Lee LM, et al. Interactions between environmental factors and melatonin receptor type $1 \mathrm{~A}$ polymorphism in relation to oral cancer susceptibility and clinicopathologic development. PloS one. 2015; 10: e0121677.

33. Cheng HL, Liu YF, Su CW, Su SC, Chen MK, Yang SF, et al. Functional genetic variant in the Kozak sequence of WW domain-containing oxidoreductase (WWOX) gene is associated with oral cancer risk. Oncotarget. 2016; 7: 69384-96.

34. Yang M, Wei X, Yang W, Li Y, Ni H, Zhao Y, et al. The polymorphisms of melatonin receptor 1B gene (MTNR1B) (rs4753426 and rs10830963) and susceptibility to adolescent idiopathic scoliosis: a meta-analysis. J Orthop Sci. 2015; 20: 593-600.

35. Xia Q, Chen ZX, Wang YC, Ma YS, Zhang F, Che W, et al. Association between the melatonin receptor $1 \mathrm{~B}$ gene polymorphism on the risk of type 2 diabetes, impaired glucose regulation: a meta-analysis. PloS one. 2012; 7: e50107.

36. Hemelt M, Yamamoto H, Cheng KK, Zeegers MP. The effect of smoking on the male excess of bladder cancer: a meta-analysis and geographical analyses. Int J Cancer. 2009; 124: 412-9.

37. Wang YH, Chiou HY, Lin CT, Hsieh HY, Wu CC, Hsu CD, et al. Association between survivin gene promoter $-31 \mathrm{C} / \mathrm{G}$ polymorphism and urothelial carcinoma risk in Taiwanese population. Urology. 2009; 73: 670-4.

38. Mao L, Yuan L, Slakey LM, Jones FE, Burow ME, Hill SM. Inhibition of breast cancer cell invasion by melatonin is mediated through regulation of the p38 mitogen-activated protein kinase signaling pathway. Breast Cancer Res. 2010; 12: R107.

39. Ram PT, Dai J, Yuan L, Dong C, Kiefer TL, Lai L, et al. Involvement of the mt1 melatonin receptor in human breast cancer. Cancer letters. 2002; 179: 141-50.

40. Jones MP, Melan MA, Witt-Enderby PA. Melatonin decreases cell proliferation and transformation in a melatonin receptor-dependent manner. Cancer letters. 2000; 151: 133-43.

41. Tsukada S, Tanaka Y, Maegawa H, Kashiwagi A, Kawamori R, Maeda S. Intronic polymorphisms within TFAP2B regulate transcriptional activity and affect adipocytokine gene expression in differentiated adipocytes. Mol Endocrinol. 2006; 20: 1104-11.

42. Wang D, Guo Y, Wrighton SA, Cooke GE, Sadee W. Intronic polymorphism in CYP3A4 affects hepatic expression and response to statin drugs. Pharmacogenomics J. 2011; 11: 274-86.

43. Hrstka R, Beranek M, Klocova K, Nenutil R, Vojtesek B. Intronic polymorphisms in TP53 indicate lymph node metastasis in breast cancer. Oncol Rep. 2009; 22: 1205-11.

44. Damavand B, Derakhshani S, Saeedi N Mohebbi SR Milanizadeh S, Azimzadeh $\mathrm{P}$, et al. Intronic polymorphisms of the SMAD7 gene in association with colorectal cancer. Asian Pac J Cancer Prev. 2015; 16: 41-4.

45. Berggren P, Hemminki K, Steineck G. p53 intron 7 polymorphisms in urinary bladder cancer patients and controls. Stockholm Bladder Cancer Group. Mutagenesis. 2000; 15: 57-60.

46. Cooper DN. Functional intronic polymorphisms: Buried treasure awaiting discovery within our genes. Hum Genomics. 2010; 4: 284-8. 